\title{
Meiofaunal production and energy transfer efficiency in a seagrass Posidonia oceanica bed in the western Mediterranean
}

\author{
Roberto Danovaro*, Cristina Gambi, Simone Mirto
}

Marine Biology Section, Faculty of Science, University of Ancona, Via Brecce Bianche, Monte D'Ago, 60131 Ancona, Italy

\begin{abstract}
Measurements of secondary production of meiofaunal assemblages are limited, and for most seagrass systems no information is available yet. In the present study meiofaunal production was estimated in a Posidonia oceanica bed in the NW Mediterranean Sea using the summation of biomass increments and different equations based on the production:biomass ratio (i.e. biomass turnover). Total meiofaunal production ranged from 7.5 to $13.2 \mathrm{~g} \mathrm{C} \mathrm{m}^{-2} \mathrm{yr}^{-1}$, according to the approach utilised (mean value $10.0 \pm 1.9 \mathrm{~g} \mathrm{C} \mathrm{m}^{-2} \mathrm{yr}^{-1}$, median value $9.6 \mathrm{~g} \mathrm{C} \mathrm{m}^{-2} \mathrm{yr}^{-1}$ ). These values are among the highest reported worldwide, indicating that seagrass systems are hot spots of meiofaunal production. Despite the numerical dominance of nematodes, harpacticoid copepods were responsible for about $50 \%$ of total meiofaunal production, followed by polychaetes and nematodes (34 and 12\%, respectively). Daily meiofaunal production rates were highest in February-March $\left(21.3 \mathrm{mg} \mathrm{C} \mathrm{m}^{-2} \mathrm{~d}^{-1}\right)$, late May-June (31.4 $\mathrm{mg} \mathrm{C} \mathrm{m}^{-2} \mathrm{~d}^{-1}$ ) and October-December (44.6 to $52.0 \mathrm{mg} \mathrm{C} \mathrm{m}^{-2} \mathrm{~d}^{-1}$ ). Analysis of daily secondary production of the dominant taxa suggested that different meiofaunal components dominated in different periods. During February-March, May-June and September-October harpacticoid copepods displayed highest production rates, but in November and December daily meiofaunal production was largely accounted for by polychaetes and nematodes. Temporal analysis of total meiofaunal production also revealed that, conversely to what is expected for temperate environments, only ca. $15 \%$ of the meiofaunal carbon was produced in summer, whereas $23 \%$ was observed in spring and $45 \%$ in autumn. Temporal changes in total meiofaunal daily production were apparently not dependent upon temperature, but rather reflected changes in the content and bio-availability of sediment organic matter in the seagrass bed. The seagrass P. oceanica was responsible, together with microphytobenthos, for high primary production values (169 to $300 \mathrm{~g} \mathrm{C} \mathrm{m}^{-2} \mathrm{yr}^{-1}$ ). The fraction of total benthic primary production potentially consumed by meiofauna (as a measure of seagrass trophic efficiency) ranged from 10 to $>50 \%$. These estimates provide evidence of the relevance of meiofauna in benthic energy flows. At the same time, the production efficiency in the Posidonia bed (calculated by the ratio of total meiofaunal production to total primary production) was only 3.0 to $5.3 \%$. These values, comparable to those observed in estuarine/organic-rich systems, are 2 to 10 times lower than those estimated in Cymodocea nodosa or Zostera noltii seagrass meadows, indicating that the Posidonia system is less efficient than other seagrass systems in channelling primary production to higher trophic levels.
\end{abstract}

KEY WORDS: Meiofauna $\cdot$ Secondary production · Energy transfer efficiency $\cdot$ Posidonia oceanica · Mediterranean Sea

Resale or republication not permitted without written consent of the publisher

\section{INTRODUCTION}

Seagrasses are among the most productive ecosystems worldwide and contribute significantly to the pro-

*E-mail: danovaro@popcsi.unian.it ductivity of coastal areas in both temperate and tropical waters (Phillips \& McRoy 1980). In the oligotrophic Mediterranean Sea, Posidonia oceanica meadows are extensively distributed at depths ranging from $<0.5$ to $>35 \mathrm{~m}$, and reach primary production (PP) values up to $3000 \mathrm{~g} \mathrm{C} \mathrm{m}^{-2} \mathrm{yr}^{-1}$, playing a key ecological role (Ott

(C) Inter-Research $2002 \cdot$ www.int-res.com 
1980). Seagrasses indeed represent an important food source for benthic consumers, offer refuge from predation to several benthic species, are nursery areas for fish juveniles, and have an important structuring role, enhancing habitat complexity, supporting epiphytes and modifying sediment texture and hydrodynamic regime (Kikuchi \& Pérès 1977, Heck \& Orth 1980, Orth \& Van Montfrans 1984, Gambi et al. 1990, Renones et al. 1995, Gacia et al. 1999, De Falco et al. 2000).

Trophic interactions in Posidonia meadows are highly complex. Though grazing activity on epiphytes can be important to vagile fauna inhabiting the leaf stratum (Gambi et al. 1992), seagrass ecosystems are assumed to be characterised by detritus-based food webs (Mateo \& Romero 1997), in which the direct consumption of living seagrass is restricted to few consumers (Mazzella et al. 1992). Due to the dominance of structural carbohydrates and to the very low protein content, phytodetritus produced by these phanerogams is highly refractory (Lawrence et al. 1989). The low degradability of seagrass carbon results in a low bio-availability of sediment organic matter (Danovaro et al. 1994). Phytodetritus produced by seagrasses needs bacterial 'aging' to become available to secondary producers (Velimirov 1986) and once degraded or converted into bacterial biomass, enters the benthic food web mostly through benthic consumers (i.e. meiofauna [Novak 1982, Danovaro 1996] and macrofauna [Lepoint et al. 2000]).

Trophic-efficient ecosystems are those able to channel PP to secondary production with minor losses. Whether seagrass systems act as detritus traps or as promoters of high secondary production is an important issue from an ecological point of view. The complexity of seagrass habitats makes it difficult to take into account all components contributing to secondary production (epiphytes, lower and upper leaf fauna, vagile fauna, benthic epifauna, infauna; Gambi et al. 1992, Zupo \& Nelson 1999). One alternative way for estimating trophic efficiency of seagrass systems is relating total primary production to the secondary production of a single benthic component. In Posidonia oceanica systems, macroinfaunal assemblages, despite their high diversity, generally show low biomass and production values (Albertelli et al. 1996), and similar values have been reported for Halophila/Heterozostera habitats from Australia (Edgar 1990). This would support the hypothesis that seagrass systems have a low trophic efficiency, but quantitative estimates are still lacking. Moreover, estimates of trophic efficiency based on macrofaunal production can be biased by the supply and/or export of larvae from/to other systems.

Meiofaunal assemblages are highly suitable for trophic efficiency assessments as: (1) they are charac- terised by life cycles spent entirely in the sediment (i.e. lack of pelagic dispersion); (2) their production is not masked by allochthonous inputs; (3) they respond promptly to all different organic matter sources and are closely coupled to primary production inputs; (4) they display high densities $\left(>10^{6}\right.$ ind. $\mathrm{m}^{-2}$ ), high turnover rates and high secondary production values (often higher than macrofaunal production), thus playing a key role in benthic energy flows (Heip et al. 1982, Feller \& Warwick 1988, Higgins \& Thiel 1988, Ceccherelli \& Mistri 1991, Danovaro \& Fabiano 1996, Albertelli et al. 1999). Moreover, meiofauna represent a direct link between producers and higher trophic levels because they are efficient in exploiting organic detritus and, at the same time, are predated upon by both macrofauna and juvenile fish (Watzin 1983, De Morais \& Bodiou 1984, Lindquist et al. 1994).

Estimates of meiofaunal production and food requirements are particularly important in seagrass systems, where the fate of the organic material released by leaf decay is unclear and estimates of the fraction of PP actually entering benthic food webs are lacking. Despite the increasing evidence of meiofaunal relevance in Posidonia oceanica meadows (Novak 1992, Danovaro 1996), information on meiofaunal secondary production and their contribution to organic carbon pathways in seagrass food webs is completely lacking.

In this study we estimated meiofaunal secondary production and provided quantitative estimates of the efficiency of a Mediterranean seagrass system (Posidonia oceanica) in channelling primary production to higher trophic levels. To do this we analysed the ratio of meiofaunal secondary production (the component assumed to be able to channel organic carbon to higher trophic levels) to total benthic primary production. Temporal patterns in meiofaunal production were also investigated to better understand factors controlling production efficiency. Finally, these estimates were compared to those calculated in different environments to provide new insights on the production efficiency of vegetated and non-vegetated coastal ecosystems.

\section{MATERIALS AND METHODS}

Study area. This study was carried out from January 1991 to January 1992 in a Posidonia oceanica bed in Prelo Bay, Golfo Marconi, Ligurian Sea (NW Mediterranean Sea; $44^{\circ} 20^{\prime} 08^{\prime \prime}$ N, 9 $12^{\prime} 09^{\prime \prime}$ E). Sediment samples were collected by SCUBA divers on a monthly basis. Sampling frequency was increased to $2 \mathrm{wk}$ intervals from March to June. The study area was sheltered and characterised by the presence of a large $P$. oceanica meadow that formed an almost continuous 
and dense belt from 0.4 to $9.0 \mathrm{~m}$ depth. The sampling station was located at $4 \mathrm{~m}$ depth where ca. 375 shoots $\mathrm{m}^{-2}$ were found. From 4 to $6 \mathrm{~m}$ depth, seagrass primary production was homogeneous, but displayed interannual changes from a minimum value of 104.5 to a maximum of $235.2 \mathrm{~g} \mathrm{C} \mathrm{m}^{-2} \mathrm{yr}^{-1}$ (Boyer 1991 and Guidetti 2000 , respectively). In this study area, primary production values within this range have been consistently reported in different years (Danovaro 1993, Danovaro et al. 1994). Microphytobenthic production, estimated in the same sampling station where seagrass primary production was measured, reached values of $64.8 \mathrm{gC}$ $\mathrm{m}^{-2} \mathrm{yr}^{-1}$ (Danovaro 1993).

Meiofaunal biomass and production. Meiofauna samples were collected in replicate cores ( $\mathrm{n}=2$ to 4 , internal diameter $3.7 \mathrm{~cm}$, surface area $10.7 \mathrm{~cm}^{2}$ ) down to a depth of $12 \mathrm{~cm}$. Sediment samples were first placed in a hot $\left(60^{\circ} \mathrm{C}\right) 0.4 \mu \mathrm{m}$ prefiltered seawater solution to relax the animals, thus allowing a better morphometric analysis, and then fixed with a $4 \%$ formaldehyde buffered solution. Sediments were sieved through 1000 and $37 \mu \mathrm{m}$ mesh. The fraction remaining on the $37 \mu \mathrm{m}$ sieve was centrifuged 3 times in Ludox HS (density $1.18 \mathrm{~g} \mathrm{~cm}^{-3}$ ) in order to separate the lighter organisms from the heavier sediment grains (Heip et al. 1985). All meiobenthic animals were counted and classified under a stereo microscope after staining with Rose Bengal $\left(0.5 \mathrm{~g} \mathrm{l}^{-1}\right)$.

Body volume of meiofaunal organisms was derived from measurements of body shape. For nematodes, body volume was calculated using Andrassy's formula:

$$
V=L(W / 2)^{2} \pi \times 10^{-6}
$$

where $V=$ the volume $(\mathrm{nl}) ; L=$ the length $(\mu \mathrm{m}) ; W=$ the width at the middle of the oesophagus $(\mu \mathrm{m})$.

For all other meiofaunal organisms, individual biovolume was estimated from body length and width using the formula:

$$
V=L \times W^{2} \times C
$$

where $L=$ body length $(\mathrm{mm}) ; W=$ body width $(\mathrm{mm})$; $C=$ the approximate conversion factors for each meiofaunal taxon (Feller \& Warwick 1988). The body volume was then multiplied by an average density $(1.13 \mathrm{~g}$ $\mathrm{cm}^{-3}$; Feller \& Warwick 1988) to obtain the biomass and the dry:wet wt ratio was taken to be 0.25 (Warwick \& Gee 1984).

The overall meiofaunal production on an annual basis was calculated in various ways to facilitate comparability of our data to those available in the literature (Heip et al. 1982):

(1) Production estimates were based on the method of summation of biomass increments at each sampling period during a year's sampling (also defined as 'minimal production', Arntz 1971):

$$
P_{\text {tot }}=\Delta B_{t_{1}-t_{0}}+\Delta B_{t_{2}-t_{1}}+\ldots \Delta B_{t_{\mathrm{n}}-t_{\mathrm{n}-1}}
$$

where $P_{\text {tot }}=$ total annual meiofaunal production; $\Delta B_{t_{1}-t_{0}}=$ the total biomass increment between 2 subsequent samplings; $t_{\mathrm{n}}-t_{0}=1 \mathrm{yr}$.

(2) Production estimates were calculated by multiplying the annual mean biomass of the entire meiofaunal assemblage by their ratio of production to biomass (i.e. biomass turnover, $\mathrm{PB})$ on an annual basis $(\mathrm{P} / \mathrm{B}=9$, according to Gerlach 1971 , or $P / B=10$, according to McIntyre 1964):

$$
P_{\text {tot }}=P / B \times B_{\text {annual }}
$$

where $B_{\text {annual }}=$ mean annual meiofaunal biomass.

(3) Production estimates were based on production: biomass ratios specific for each taxon (i.e. $P / B=8.4$ for nematodes, 18 for harpacticoids, and 5 for annelids and turbellarians, according to Warwick et al. 1979; or $\mathrm{P} / \mathrm{B}=9.75$ for nematodes, 21 for copepods, 11.3 for turbellarians, 9.7 for annelids, and 9.12 for other taxa according to Lasserre et al. 1976):

and

$$
P_{\text {tot }}=P_{\text {nem }}+P_{\text {cop }}+P_{\text {anel }}+P_{\text {turb }}+P_{\text {oth }}
$$

$$
P_{\text {taxon }}=P / B_{\text {taxon }} \times B_{\text {taxon }}
$$

where $P_{\text {nem }}=$ total nematode production; $P_{\text {cop }}=$ total harpacticoid copepod production; $P_{\text {anel }}=$ total annelid production, $P_{\text {turb }}=$ total turbellarian production; $P_{\text {oth }}=$ total production of all others meiofaunal taxa; $P_{\text {taxon }}=$ annual production of each taxon; $P / B_{\text {taxon }}=$ annual biomass turnover of each taxon; $B_{\text {taxon }}=$ annual mean biomass of each taxon.

Direct methods for estimating total meiofaunal production (e.g. species-specific growth increments, identifiable cohorts) are operationally not feasible at a community level, because of the taxonomic difficulty in identifying meiofauna to species level, and because of the small size of meiofaunal organisms (Higgins \& Thiel 1988). Moreover, in situ estimates based on oxygen consumption are not possible because meiofauna respiration can not be efficiently distinguished from bacteria and protozoa oxygen consumption. At the same time, the approaches we used are limited since the methods of biomass-increment summations underestimate the value of total meiofaunal production. Methods based on annual $P: B$ ratios are subjected to problems of accuracy (Warwick 1980). $P: B$ ratios are variable within each taxon (a range of 4 to 63 was observed for nematodes, Vranken et al. 1986). Moreover, it is not easy to establish a single $P: B$ ratio for the entire community (Vranken \& Heip 1986). Therefore, we recognise that methods used here need further validation with other specific estimates, but still remain the only way to provide comparable values of total meiofaunal secondary production (McIntyre 1964, Ankar \& Elmgren 1976, Warwick et al. 1979, Escar- 
avage et al. 1989, Chardy \& Dauvin 1992, Chardy et al. 1993, Danovaro \& Fabiano 1996).

The temporal analysis of meiofaunal secondary production (MP) was investigated by identifying which periods displayed highest biomass increments, and which biotic/environmental factors were responsible for such changes. In this case we applied the Warwick's fractionated $P: B$ ratios to each sampling period, as follows:

$$
\begin{aligned}
\mathrm{MP}= & \sum_{i=1}^{\mathrm{n}} \frac{\mathrm{MBM}_{t} \times P / B_{t}}{T_{1}}+\sum_{i=1}^{\mathrm{n}} \frac{\mathrm{MBM}_{t} \times P / B_{t}}{T_{2}} \\
& +\ldots \sum_{i=1}^{\mathrm{n}} \frac{\mathrm{MBM}_{t} \times P / B_{t}}{T_{\mathrm{n}}}
\end{aligned}
$$

and

$$
\mathrm{MP}_{T_{1}}+\mathrm{MP}_{T_{2}}+\mathrm{MP}_{T_{\mathrm{n}}} \ldots=1 \mathrm{yr}
$$

where $\mathrm{MP}=$ meiofaunal secondary production $\left(\mathrm{g} \mathrm{C} \mathrm{m}^{-2}\right.$ $\left.\mathrm{yr}^{-1}\right) ; \mathrm{n}=$ number of taxa; $\mathrm{MBM}_{t}=$ the average meiofaunal biomass of each taxon at each sampling interval; $P / B_{t}=$ the production to biomass ratio utilised for each taxon on a daily basis and calculated by dividing the annual $P: B$ ratio by the number of days of each sampling period; $T=$ the number of days between 2 subsequent samplings; $T_{1}, T_{2}, T_{\mathrm{n}}=$ is the sequential number of sampling intervals; $\mathrm{MP}_{T_{1}}=$ is meiofaunal production determined for each sampling interval.

Meiofaunal energetic demand and estimates of trophic and production efficiency. Information available on conversion factors applicable for estimates in meiofaunal energetic demand is extremely limited. Carbon conversion factors are needed to estimate the amount of carbon required (i.e. food demand) for yielding a unit of secondary production. Estimates of food demand are generally made using conservative factors, which have the main limit of not taking into account temporal variability in benthic metabolism and/or organic carbon bioavailability (Danovaro et al. 2001). The C-conversion efficiency factors utilised in literature are: (1) $32.5 \%$, based on direct metabolic measurements (Warwick et al. 1979). This value has been corroborated by direct estimates based on respiration rates (30 to $40 \%$, Herman et al. 1984); (2) $10 \%$, based on the Lindeman concept of flux energy through trophic levels within an ecosystem (Bouvy 1988). In order to take into account errors due to the use of different conversion factors, meiofauna food demand was estimated using both factors as follows:

$$
\mathrm{MFD}=\mathrm{MP} / \mathrm{CCE}
$$

where MFD = meiofaunal food demand $\left(\operatorname{as~} \mathrm{g} \mathrm{C} \mathrm{m}^{-2} \mathrm{yr}^{-1}\right)$; $\mathrm{CCE}=$ carbon conversion efficiency (i.e. 32.5 or $10 \%$ ).

The ratio of meiofauna food demand to total primary production (microphytobenthic production plus Posidonia oceanica production) represents the fraction of primary production utilised for meiofaunal growth (i.e. trophic efficiency expressed as percentage).

$$
\mathrm{TE}=\mathrm{MP} / \mathrm{BPP} \times 100
$$

where $\mathrm{TE}=$ trophic efficiency; $\mathrm{BPP}=$ total benthic primary production (as $\mathrm{gC} \mathrm{m}^{-2} \mathrm{yr}^{-1}$ ). The production efficiency (PE) was estimated as the ratio of MP to total primary production (as seagrass plus microphytobenthic primary production, from the same sampling station and based on synoptic samplings):

$$
\mathrm{PE}=P_{t} / P_{t-1}
$$

where $\mathrm{PE}=$ production efficiency (expressed as percentage) $P_{t-1}=$ the production of the exploited trophic level (in this case BPP); $P_{t}=$ the production of the higher trophic level (in this case MP).

\section{RESULTS AND DISCUSSION}

\section{Meiofaunal biomass and production in seagrass Posidonia oceanica beds}

The range of individual body weights of the main meiofaunal taxa encountered in the Posidonia oceanica bed (Table 1a) overlapped with those previously reported from other coastal environments (see Higgins \& Thiel 1988: review). The only exception was represented by nematodes, which displayed an individual biomass higher than values reported in the Atlantic and North Sea coasts $\left(0.2\right.$ to $0.5 \mu \mathrm{gC}$ ind. ${ }^{-1}$; Witte \& Zijlstra 1984, Escaravage et al. 1989). However, this feature can be typical of seagrass systems as similar values have been repeatedly reported by Novak (1989) and Danovaro et al. (1999) from different Mediterranean Posidonia systems. Despite their body size and their dominance in terms of density (on annual average nematodes accounted for $44 \%$ of total meiofaunal density), nematodes biomass (range: $0.2 \pm 0.1$ to $4.8 \pm$ $2.5 \mathrm{gC} \mathrm{m}^{-2}$ in April and November, respectively; Table $1 \mathrm{~b}$ ) accounted only for $12 \%$ of total meiofaunal biomass, which was mostly accounted by polychaetes $(58 \%)$ and harpacticoid copepods $(23 \%)$. The average individual biomass of all taxa was characterised by a high degree of variability (Table 1). Such large variability requires great caution when $P: B$ ratio-based estimates of secondary production are calculated.

Total meiofaunal biomass in the investigated Posidonia oceanica bed (on average $1.0 \mathrm{~g} \mathrm{C} \mathrm{m}^{-2}$ ) was comparable to values reported from other Mediterranean seagrass systems (Novak 1989) and in a nearby sandy areas characterised by the presence of Cymodocea nodosa (average meiofaunal biomass: $0.8 \mathrm{~g} \mathrm{C} \mathrm{m}^{-2}$; Danovaro \& Fabiano 1996). High meiofaunal biomass values (range: 1.2 to $2.4 \mathrm{gC} \mathrm{m}^{-2}$ 
equivalent to 2.98 to $6.01 \mathrm{~g}$ dry $\mathrm{wt} \mathrm{m}^{-2}$ ) have been also reported in Zostera noltii beds along the Atlantic coast (Escaravage et al. 1989). Such comparisons are not biased by variability in biomass estimates since, on annual average, the coefficient of variation for total meiofaunal biomass was $42.9 \%$. Therefore, it is possible to conclude that meiofaunal biomass in the Posidonia oceanica bed was high, thus reflecting the large organic carbon inputs provided by benthic primary production.

Often comparisons of secondary production from different areas are difficult because different methods are used for their estimation. In the present study, all different calculation methods of total meiofaunal production provided similar results (Table 2), displaying a coefficient of variation of $19 \%$. As expected, the lowest estimate of total meiofaunal production $\left(7.5 \mathrm{gC} \mathrm{m}^{-2}\right.$ $\mathrm{yr}^{-1}$ ) was obtained using Arntz's method (also defined minimal production because it does not take into account predatory losses), whereas the highest value (13.2 $\mathrm{g} \mathrm{C} \mathrm{m}^{-2} \mathrm{yr}^{-1}$ ) was obtained using the fractionated $P: B$ ratios proposed by Lasserre et al. (1976). Meiofaunal production estimates in the Posidonia oceanica bed (mean value $10.0 \pm 1.9 \mathrm{gC} \mathrm{m}^{-2} \mathrm{yr}^{-1}$, median value $9.6 \mathrm{~g} \mathrm{C} \mathrm{m}^{-2} \mathrm{yr}^{-1}$ ) were 4 to 5 times higher than those reported in the North and in the Baltic Sea (McIntyre 1964, Ankar \& Elmgren 1976) or in the Atlantic (Chardy \& Dauvin 1992, Chardy et al. 1993). Similarly high values in subtidal sediments have been reported only from other seagrass systems and estuarine environments (Warwick et al. 1979, Escaravage et al. 1989). Such differences are so important that they cannot be masked by the variability associated with the method used for estimating secondary production nor by the variability associated with the meiofaunal biomass estimates.

Table 1. Individual (a) and total biomass (b) of nematodes, copepods, polychaetes, turbellarians and others organism (0 to 4 cm) during 1991-1992 study period. na: not available

\begin{tabular}{|c|c|c|c|c|c|c|c|c|c|c|c|c|}
\hline \multirow{2}{*}{$\begin{array}{l}\text { (a) } \\
\text { Date }\end{array}$} & \multicolumn{2}{|c|}{ Nematodes } & \multicolumn{3}{|c|}{ Copepods } & \multicolumn{2}{|c|}{ Polychaetes } & \multicolumn{3}{|c|}{ Turbellarians } & \multicolumn{2}{|c|}{ Other taxa } \\
\hline & $\mu g \mathrm{C}$ ind.$^{-1}$ & $\pm \mathrm{SD}$ & \multicolumn{2}{|c|}{$\mu g C$ ind..$^{-1}$} & $\pm \mathrm{SD}$ & $\mathrm{C}$ ind..$^{-1}$ & $\pm \mathrm{SD}$ & \multicolumn{2}{|c|}{$\mu g \mathrm{C}$ ind..$^{-1}$} & $\pm \mathrm{SD}$ & $\mu \mathrm{g} C$ ind $^{-1}$ & $\pm \mathrm{SD}$ \\
\hline 17 Jan 91 & 0.8 & 1.3 & \multicolumn{2}{|c|}{1.8} & 1.5 & 28.7 & 32.5 & \multicolumn{2}{|l|}{8.0} & 7.9 & 1.3 & 0.5 \\
\hline 20 Feb 91 & 0.8 & 0.9 & \multicolumn{2}{|c|}{1.6} & 6.3 & 33.1 & 31.3 & \multicolumn{2}{|l|}{3.8} & 4.1 & 7.0 & 2.8 \\
\hline 21 Mar 91 & 0.7 & 0.9 & \multicolumn{2}{|c|}{1.8} & 6.1 & 5.3 & 15.6 & \multicolumn{2}{|l|}{4.9} & 6.2 & 1.3 & 0.5 \\
\hline 08 Apr 91 & 0.8 & 0.4 & \multicolumn{2}{|c|}{1.6} & 1.8 & 66.2 & 18.2 & \multicolumn{2}{|l|}{5.6} & 4.4 & 4.0 & 1.6 \\
\hline 22 Apr 91 & 1.0 & 0.7 & 1.4 & & 0.3 & 43.0 & 6.1 & 3.7 & & & 2.1 & 0.8 \\
\hline 08 May 91 & 1.0 & 1.2 & 0.5 & & 0.4 & 18.9 & 21.6 & 1.8 & & & 4.6 & 1.8 \\
\hline 30 May 91 & 1.0 & 2.1 & 0.9 & & 2.9 & 19.3 & 19.2 & 1.8 & & & 1.8 & 0.7 \\
\hline 28 Jun 91 & 0.6 & 0.5 & 1.3 & & 1.7 & 36.9 & 47.8 & 3.0 & & & 9.4 & 3.8 \\
\hline 18 Jul 91 & 0.6 & 1.0 & 0.7 & & 0.8 & 14.9 & 19.8 & 0.6 & & & 0.0 & 0.0 \\
\hline 01 Aug 91 & 0.5 & 0.3 & 0.3 & & 0.4 & 7.2 & 5.7 & 2.2 & & & 48.1 & 19.3 \\
\hline 05 Sep 91 & 0.8 & 1.4 & 1.4 & & 1.8 & 8.9 & 7.8 & 2.2 & & & 3.2 & 1.3 \\
\hline 31 Oct 91 & 0.4 & 0.5 & 0.3 & & 0.2 & 7.8 & 6.4 & na & & & 2.3 & 0.9 \\
\hline 30 Nov 91 & 1.5 & 2.0 & 1.7 & & 4.2 & 43.9 & 28.2 & 3.6 & & & 5.6 & 2.2 \\
\hline 23 Dec 91 & 0.3 & 0.2 & 0.4 & & 0.4 & 18.8 & 23.7 & 1.3 & & & 2.3 & 0.9 \\
\hline 07 Jan 92 & 0.1 & 0.1 & 0.2 & & 0.2 & 7.5 & 9.5 & 0.5 & & & 2.7 & 1.1 \\
\hline (b) & Nemat & odes & Cope & ods & Polych & laetes & Turbell & rians & Oth & & Meiof & una \\
\hline Date & $\mathrm{gC} \mathrm{m}^{-2}$ & $\pm \mathrm{SD}$ & $\mathrm{gC} \mathrm{m}^{-2}$ & $\pm \mathrm{SD}$ & $\mathrm{gC} \mathrm{m}^{-2}$ & $\pm \mathrm{SD}$ & $\mathrm{gC} \mathrm{m}^{-2}$ & $\pm \mathrm{SD}$ & $\mathrm{gC} \mathrm{m}^{-2}$ & $\pm \mathrm{SD}$ & $\mathrm{gC} \mathrm{m} \mathrm{m}^{-2}$ & $\pm \mathrm{SD}$ \\
\hline 17 Jan 91 & 0.17 & 0.24 & 0.09 & 0.09 & 0.35 & 0.00 & 0.18 & 0.20 & 0.01 & 0.01 & 0.79 & 0.55 \\
\hline 20 Feb 91 & 0.06 & 0.01 & 0.29 & 0.20 & 0.63 & 0.02 & 0.12 & 0.07 & 0.03 & 0.01 & 1.13 & 0.32 \\
\hline 21 Mar 91 & 0.04 & 0.05 & 0.25 & 0.08 & 0.08 & 0.02 & 0.09 & 0.01 & 0.01 & 0.00 & 0.48 & 0.17 \\
\hline 08 Apr 91 & 0.05 & 0.02 & 0.01 & 0.09 & 0.12 & 0.00 & 0.02 & 0.00 & 0.02 & 0.01 & 0.22 & 0.12 \\
\hline 22 Apr 91 & 0.03 & 0.02 & 0.18 & 0.06 & 1.23 & 0.19 & 0.10 & 0.01 & 0.01 & 0.01 & 1.54 & 0.28 \\
\hline 08 May 91 & 0.11 & 0.15 & 0.06 & 0.04 & 0.19 & 0.23 & 0.02 & 0.02 & 0.01 & 0.01 & 0.39 & 0.44 \\
\hline 30 May 91 & 0.14 & 0.14 & 0.42 & 0.08 & 0.44 & 0.10 & 0.03 & 0.01 & 0.02 & 0.01 & 1.05 & 0.34 \\
\hline 28 Jun 91 & 0.04 & 0.06 & 0.48 & 0.12 & 0.43 & 0.13 & 0.04 & 0.09 & 0.04 & 0.02 & 1.03 & 0.41 \\
\hline 18 Jul 91 & 0.08 & 0.06 & 0.16 & 0.06 & 0.26 & 0.05 & 0.02 & 0.02 & 0.02 & 0.02 & 0.53 & 0.21 \\
\hline 01 Aug 91 & 0.15 & 0.06 & 0.08 & 0.04 & 0.18 & 0.05 & 0.07 & 0.05 & 0.02 & 0.02 & 0.50 & 0.21 \\
\hline 05 Sep 91 & 0.23 & 0.09 & 0.32 & 0.08 & 0.15 & 0.04 & 0.01 & 0.00 & 0.02 & 0.01 & 0.73 & 0.22 \\
\hline 31 Oct 91 & 0.10 & 0.01 & 0.32 & 0.03 & 0.41 & 0.13 & 0.00 & 0.00 & 0.02 & 0.00 & 0.85 & 0.18 \\
\hline 30 Nov 91 & 0.34 & 0.27 & 0.32 & 0.13 & 4.00 & 2.05 & 0.07 & 0.05 & 0.01 & 0.00 & 4.75 & 2.50 \\
\hline 23 Dec 91 & 0.07 & 0.05 & 0.06 & 0.06 & 0.28 & 0.08 & 0.02 & 0.01 & 0.03 & 0.01 & 0.46 & 0.21 \\
\hline 07 Jan 92 & 0.20 & 0.11 & 0.03 & 0.02 & 0.23 & 0.11 & 0.03 & 0.01 & 0.01 & 0.01 & 0.50 & 0.26 \\
\hline
\end{tabular}


Table 2. Meiofaunal production in Prelo Bay and other areas

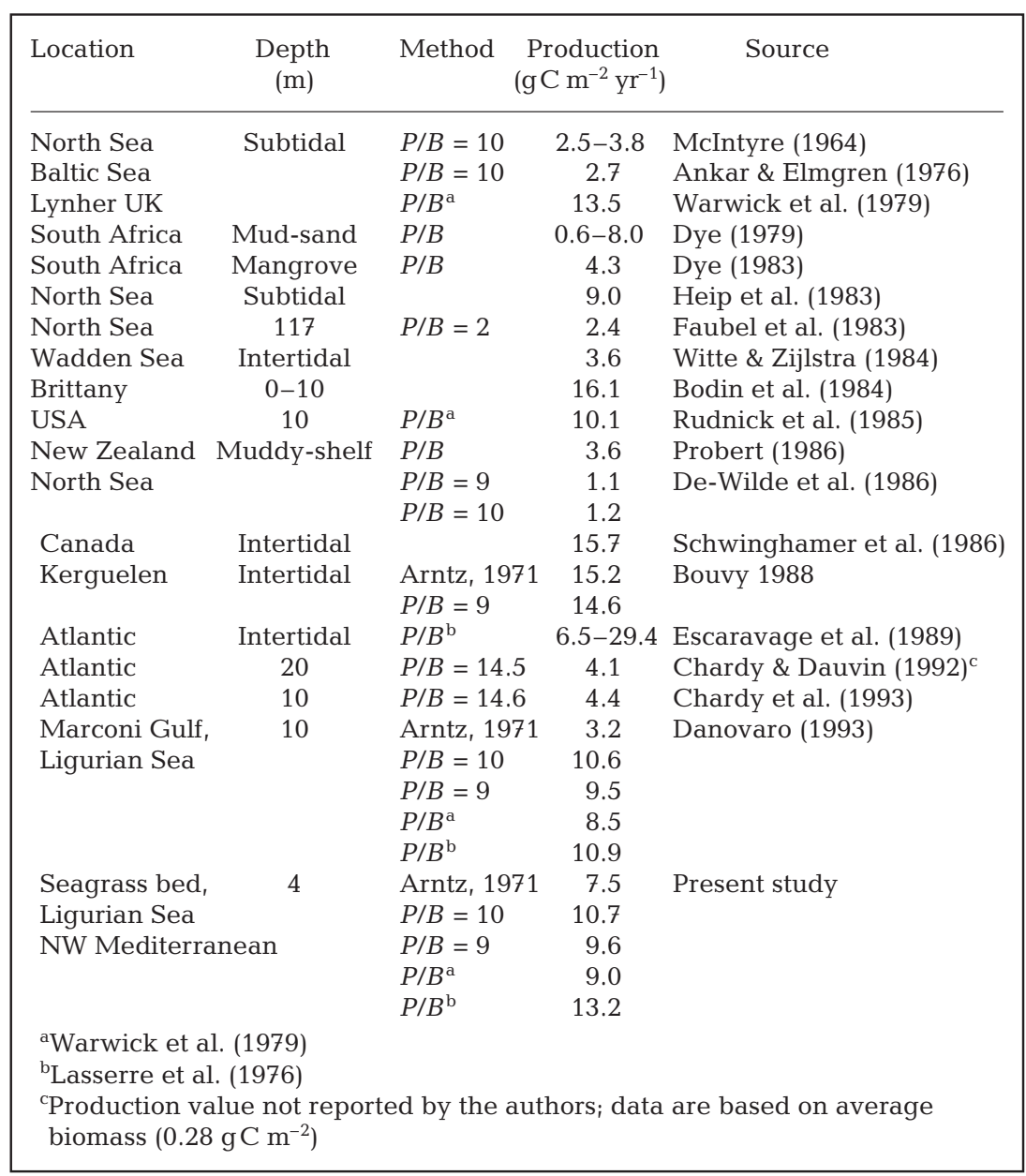

Tachidius discipes (0.98 to $1.01 \mathrm{~g} \mathrm{C}$ $\mathrm{m}^{-2} \mathrm{yr}^{-1}$, Herman et al. 1984).

The annual turnover rate (as life cycle turnover $\times$ number of generations) has been estimated to approximate 9 to 10 for the meiofauna (Coull 1988). Turnover rates are a very difficult parameter to quantify as they depend upon the reproductive potential of the different meiofaunal species, but also on a number of environmental factors (temperature, food supply and availability), which can influence total meiofaunal production and benthic trophic efficiency in exploiting food sources. Biomass turnover rates can be expressed as the ratio of production to biomass. Danovaro (1993) reported a $P: B$ ratio for the entire meiofaunal assemblage of ca. 3 from sandy sediments. Similar $P / B$ values have been calculated from respiration experiments based on different life stages of crustacean meiofaunal populations $(P / B=3$, Herman et al. 1984; $P / B=3.6$, Feller 1982). In the present study, total meiofaunal production estimated using Arntz's method allowed estimating the overall annual biomass turnover rate of $7.5(P / B$, calculated as the
Using equations provided by Warwick et al. (1979) for the calculation of the meiofaunal production of each taxon, it was possible to estimate that copepods provided the highest contribution (ca. $50 \%$, i.e. $4.45 \mathrm{~g} \mathrm{C} \mathrm{m}^{-2} \mathrm{yr}^{-1}$ ) to the total meiofaunal production, followed by polychaetes and nematodes (34 and 12\%, respectively; Table 3). The high secondary production of harpacticoid copepod in this seagrass bed confirmed the relevance of this taxon in systems characterised by strong vegetation cover (Coull et al. 1983, Hicks 1985). Our values of secondary production, though based on a whole taxon, are comparable to those reported for dominant copepod species from different coastal environments, such as Canuella perplexa (2.4 to $2.7 \mathrm{~g} \mathrm{C} \mathrm{m}^{-2} \mathrm{yr}^{-1}$ from a brackish-water Mediterranean lagoon, Ceccherelli \& Mistri 1991); Huntemannia jadensis (0.7 to $1.7 \mathrm{~g} \mathrm{C} \mathrm{m}^{-2} \mathrm{yr}^{-1}$, Feller 1982), Microarthridion littorale $\left(0.6 \mathrm{gC} \mathrm{m}^{-2}\right.$ $\mathrm{yr}^{-1}$, Fleeger \& Palmer 1982), and ratio of total annual meiofaunal production to annual average biomass). This value was close to those generally reported for meiofaunal assemblages (McIntyre 1964, Gerlach 1971) and about double of those reported for more oligotrophic sandy habitats (Danovaro 1993), suggesting the presence of higher rates in these organic-rich environments. However, $P: B$ ratio-based estimates of secondary production must be viewed with caution since the assumption of
Table 3. Relative contribution of different taxa to total meiofaunal production (0 to $4 \mathrm{~cm}$ ) calculated using the method of Warwick et al. (1979)

\begin{tabular}{|lrccc|}
\hline & $P / B$ & $\begin{array}{c}\text { Biomass } \\
\left(\mathrm{g} \mathrm{C} \mathrm{m}^{-2}\right)\end{array}$ & $\begin{array}{c}\text { Production } \\
\left(\mathrm{g} \mathrm{C} \mathrm{m}^{-2} \mathrm{yr}^{-1}\right)\end{array}$ & $\begin{array}{c}\text { Contribution } \\
(\%)\end{array}$ \\
\hline Nematodes & 8.40 & 0.13 & 1.05 & 11.6 \\
Harpacticoid copepods & 18.00 & 0.25 & 4.45 & 49.7 \\
Polychaetes & 5.00 & 0.62 & 3.11 & 34.4 \\
Turbellarians & 5.00 & 0.05 & 0.26 & 2.8 \\
Others & 9.12 & 0.02 & 0.18 & 2.0 \\
Total & & 1.07 & 9.05 & \\
\hline
\end{tabular}


average turnover ratios accrues errors due to sampling variance and the variability of biomass estimates.

Temporal changes in meiofaunal production are reported in Table 4 . Total daily meiofaunal production displayed evident temporal changes, with highest values in February-March (21.3 $\left.\mathrm{mg} \mathrm{C} \mathrm{m}^{-2} \mathrm{~d}^{-1}\right)$, late MayJune (31.4 $\left.\mathrm{mg} \mathrm{C} \mathrm{m}^{-2} \mathrm{~d}^{-1}\right)$ and October-December (44.6 to $52.0 \mathrm{mg} \mathrm{C} \mathrm{m}^{-2} \mathrm{~d}^{-1}$ ). However, conversely to what is generally expected for temperate environments (in which higher meiobenthic density and production are expected in summer, Soyer [1985]), our estimates of daily meiofaunal production indicated that about $45 \%$ of the $P_{\text {tot }}$ occurred in autumn, ca. $23 \%$ in spring, $17 \%$ in winter and $15 \%$ in summer. Since most daily production values during the 'warm season' (e.g. those from July to September, when water temperature is $>20^{\circ} \mathrm{C}$ ) lie $<20 \mathrm{mg} \mathrm{C} \mathrm{m}^{-2} \mathrm{~d}^{-1}$, it is possible to conclude that temporal trends of total meiofaunal production are not temperature-dependent. Therefore, temporal fluctuations in daily production rates must be driven by other factors. In the seagrass system, all periods of high secondary production corresponded to microphytobenthic blooms in February-March and late May-June, and to the release of seagrass leaves and their epiphytes in November-December (Danovaro 1996). Therefore, it is likely that temporal changes in total meiofaunal daily production reflected changes in the content and bio-availability of sediment organic matter in the seagrass bed.

The analysis of daily secondary production of the dominant taxa also suggested that different meiofaunal components dominated in different periods. During February-March, May-June and September-October harpacticoid copepods displayed high daily production rates. However, total daily meiofaunal production in
November and December was largely accounted for by polychaete and nematode production.

\section{Trophic and production efficiency in Posidonia oceanica seagrass systems}

In this paper we provided the first estimates of trophic efficiency and production efficiency in a seagrass system. The trophic efficiency was defined as the fraction of total PP that was directly or indirectly channelled (or converted) into meiofaunal production. The fraction of total PP potentially utilised by meiofauna can be estimated from meiofaunal food demand. Using the 2 conversion factors available in the literature (32.5 and 10\%, Warwick et al. 1979 and Bouvy 1988, respectively), it is possible to estimate a meiofauna food demand of 27.9 to $90.5 \mathrm{gC} \mathrm{m}^{-2} \mathrm{yr}^{-1}$ (Table 5). Though phytoplankton PP in the same area can reach $61.5 \mathrm{gC} \mathrm{m}^{-2} \mathrm{yr}^{-1}$ (Fabiano 1984), this contribution was not considered in our budget of total PP since the production of phytoplankton reaching seagrass sediments at $4 \mathrm{~m}$ depth was included into estimates of microphytobenthic PP. Therefore, assuming a range of total benthic primary production (BPP as seagrass plus microphytobenthic PP) of 169 to $300 \mathrm{gC}$ $\mathrm{m}^{-2} \mathrm{yr}^{-1}$ (this range is the widest possible and includes all errors associated with the spatial and temporal variability) meiofaunal food demand would be equivalent to 17 to $54 \%$ and 10 to $30 \%$ (assuming the lowest and the highest BPP values, respectively) of the total benthic primary production (Table 5). Overall, these estimates provide quantitative evidence of the relevance of meiofauna in benthic energy flows, indicating that 10 to $50 \%$ of the PP in a seagrass system

Table 4. Nematode, copepod, polychaete, turbellarian and other group production during the sampling period, daily production of each taxon and their relative contribution to the total annual meiofaunal production (MP)

\begin{tabular}{|c|c|c|c|c|c|c|c|c|c|}
\hline $\begin{array}{l}\text { Sampling } \\
\text { periods }\end{array}$ & $\begin{array}{l}\text { Interval } \\
\text { (d) }\end{array}$ & Nematodes & Copepods & $\begin{array}{l}\text { Polychaetes } \\
-\left(\mathrm{gC} \mathrm{m}^{-2} \text { in }\right.\end{array}$ & $\begin{array}{l}\text { Turbel- } \\
\text { larians } \\
\text { erval }^{-1} \text { ) }\end{array}$ & Others & $\begin{array}{c}\text { Total } \\
\text { production }\end{array}$ & $\begin{array}{c}\text { Daily } \\
\text { production } \\
\left(\mathrm{mgC} \mathrm{m}^{-2} \mathrm{~d}^{-1}\right)\end{array}$ & $\begin{array}{c}\text { Control to } \\
\text { total MP } \\
(\%)\end{array}$ \\
\hline Jan-Feb & 34 & 0.09 & 0.31 & 0.23 & 0.07 & 0.02 & 0.72 & 21.1 & 8.2 \\
\hline Feb-Mar & 29 & 0.03 & 0.39 & 0.14 & 0.04 & 0.01 & 0.62 & 21.3 & 7.0 \\
\hline Mar-Apr 1 & 18 & 0.02 & 0.12 & 0.03 & 0.01 & 0.01 & 0.18 & 10.0 & 2.0 \\
\hline Apr 1-Apr 2 & 14 & 0.01 & 0.07 & 0.13 & 0.01 & 0.00 & 0.22 & 16.0 & 2.5 \\
\hline Apr 2-May 1 & 16 & 0.03 & 0.10 & 0.16 & 0.01 & 0.00 & 0.29 & 18.3 & 3.3 \\
\hline May 1-May 2 & 222 & 0.06 & 0.26 & 0.09 & 0.01 & 0.01 & 0.43 & 19.7 & 4.9 \\
\hline May 2-Jun & 29 & 0.04 & 0.64 & 0.17 & 0.02 & 0.02 & 0.91 & 31.4 & 10.3 \\
\hline Jun-Jul & 20 & 0.04 & 0.47 & 0.14 & 0.01 & 0.02 & 0.69 & 34.5 & 7.8 \\
\hline Jul-Aug & 14 & 0.01 & 0.02 & 0.01 & 0.00 & 0.00 & 0.05 & 3.6 & 0.6 \\
\hline Aug-Sep & 35 & 0.15 & 0.35 & 0.08 & 0.02 & 0.02 & 0.62 & 17.6 & 7.0 \\
\hline Sep-Oct & 56 & 0.21 & 0.88 & 0.22 & 0.01 & 0.03 & 1.34 & 24.0 & 15.3 \\
\hline Oct-Nov & 30 & 0.15 & 0.47 & 0.91 & 0.01 & 0.01 & 1.56 & 52.0 & 17.7 \\
\hline Nov-Dec & 23 & 0.11 & 0.22 & 0.67 & 0.01 & 0.01 & 1.02 & 44.3 & 11.6 \\
\hline Dec-Jan & 16 & 0.05 & 0.03 & 0.05 & 0.01 & 0.01 & 0.15 & 9.1 & 1.7 \\
\hline
\end{tabular}


Table 5. Energetic demand of meiobenthos compared to microphytobenthic and Posidonia oceanica production as potential food sources

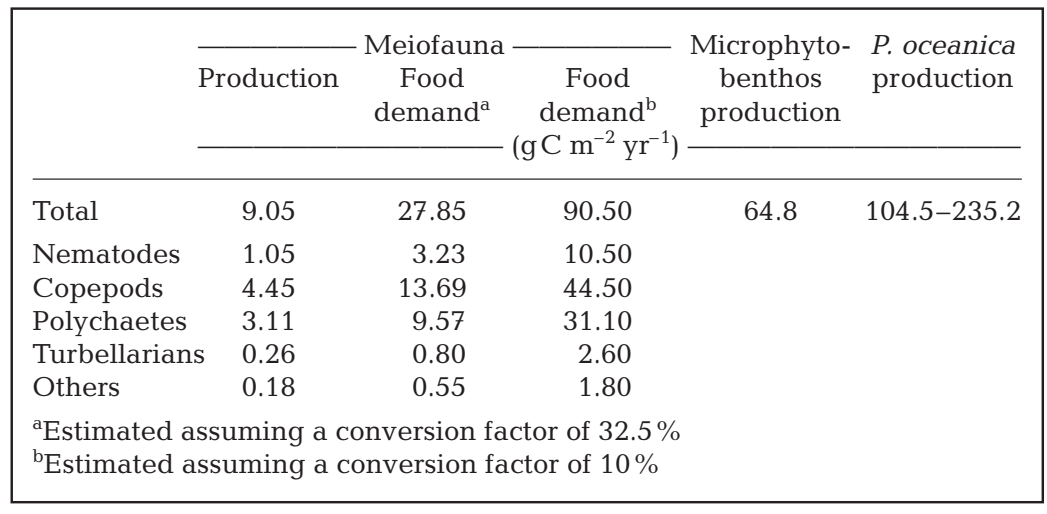

and comparable to those observed for high-energy or estuarine organic-rich systems. One might conclude that this is the obvious consequence of the highly refractory composition of seagrass leaves and their phytodetritus, which is known to be largely unavailable to benthic consumers (Pirc \& Wollenveber 1988, Danovaro et al. 1999). However, estimates of PE from a $P$. oceanica system were 2 to 10 times lower than those calculated in Cymodocea nodosa and Zostera noltii seagrass systems from Mediterranean and Atlantic coastal areas (Table 6). It is possible that such low PEs are bal-

can be channelled through meiofauna (including all possible errors in our estimates).

The production efficiency (PE) is generally employed as a measure of the efficiency of energy transfer from one trophic level to the next, and is calculated as the energy produced by one trophic level compared to the production of the exploited trophic level. Besides the difficulties in obtaining reliable production estimates, the ecological efficiency calculated in this way can be biased by the fact that meiofaunal organisms do not represent all consumers of PP present in a seagrass meadow (Velimirov 1991, Gambi et al. 1992). Nonetheless, PEs based on meiofaunal assemblages represent wide-spectrumindicators of the energy transfer from producers to consumers (Higgins \& Thiel 1988). In the Posidonia oceanica system, the PE was 3.0 to $5.3 \%$ (calculated as the ratio of $P_{\text {tot }}$ to total PP; Table 6). The detailed analysis of the PE from different locations (based on homogeneous calculation methods and conversion factors) revealed that our values were very low anced by a fraction of PP entering benthic food webs through macrofauna or other benthic boundary components. Nonetheless, our results suggest that $P$. oceanica meadows are less efficient than other seagrass systems in the transfer of energy to higher trophic levels.

Further investigations are needed to clarify the reason of such different ecological efficiencies and the extent of errors associated to estimates of MP, but the development of this approach for estimating benthic trophic efficiency, and its extension to other benthic components, can be a promising approach for comparing carbon transfer and energy budgets in different benthic coastal systems.

Acknowledgements. We are particularly grateful to Prof. Mauro Fabiano (University of Genoa), Dr. Antonio Dell'Anno and Dr. Antonio Pusceddu (University of Ancona) and Dr. P. Guidetti (University of Lecce) and 3 anonymous reviewers for their useful suggestions. This work was partially supported by Ministero dell'Università e della Ricerca Scientifica, $60 \%$, Italy.

Table 6. Comparison of production efficiency from different locations

\begin{tabular}{|c|c|c|c|c|c|c|}
\hline Location & $\begin{array}{l}\text { Environmental } \\
\text { features }\end{array}$ & Depth & $\begin{array}{l}\text { Meiofauna } \\
\text { production } \\
\left(\mathrm{gC} \mathrm{m}^{-2} \mathrm{yr}^{-1}\right)\end{array}$ & $\begin{array}{c}\text { Benthic } \\
\text { primary production } \\
\left(\mathrm{gC} \mathrm{m}^{-2} \mathrm{yr}^{-1}\right)\end{array}$ & $\begin{array}{l}\text { Production } \\
\text { efficiency } \\
(\%)\end{array}$ & Source \\
\hline Atlantic & Estuarine mud flat & Intertidal & 19.5 & $57.3-87.9$ & $22.1-33.9$ & Escaravage et al. (1989) \\
\hline Atlantic & Zostera bed & Intertidal & 13.0 & $40.6-85.7$ & $15.2-32.1$ & Escaravage et al. (1989) \\
\hline Atlantic & Zostera bed & Intertidal & 29.4 & $95.1-141.2$ & $20.8-30.9$ & Escaravage et al. (1989) \\
\hline Atlantic & Sand unvegetated & Intertidal & 6.5 & $26.1-44.2$ & $14.7-24.9$ & Escaravage et al. (1989) \\
\hline Atlantic & Sand unvegetated & Intertidal & 5.1 & $25.7-34.0$ & $15.1-19.9$ & Escaravage et al. (1989) \\
\hline Mediterranean & Cymodocea & $10 \mathrm{~m}$ & 8.5 & $72.5-95.1$ & $8.9-11.7$ & Danovaro \& Fabiano (1996) \\
\hline Atlantic & Oyster Park & Intertidal & 11.8 & $121.3-162.1$ & $7.3-9.7$ & Escaravage et al. (1989) \\
\hline Atlantic & Fine coastal sands & $7 \mathrm{~m}$ & 8.1 & $87.2-109.4$ & $7.4-9.3$ & Escaravage et al. (1989) \\
\hline Atlantic & Estuarine silt-clay & Intertidal & 11.0 & $250-300^{\mathrm{a}}$ & $3.7-4.4$ & Rudnick et al. (1985) \\
\hline South Africa & Dune slacks & Intertidal & 3.6 & 95.0 & 3.8 & McLachlan et al. (1996) \\
\hline Wadden Sea & Silt & Intertidal & 3.6 & 200.0 & 1.8 & Witte \& Zijlstra (1984) \\
\hline Atlantic & Fine sand & $20 \mathrm{~m}$ & 4.1 & 219.0 & 1.8 & Chardy \& Dauvin (1992) \\
\hline Mediterranean & Posidonia bed & Intertidal & 9.0 & $169.3-300.0$ & $3.0-5.3$ & Present study \\
\hline
\end{tabular}




\section{LITERATURE CITED}

Albertelli G, Covazzi-Harriague A, Doidge-Harrison SA (1996) A preliminary study of a soft-bottom community in Prelo Cove (Ligurian Sea, Italy): a comparison with a sandy-bottom community. In: Albertelli G, De Maio A, Picazzo M (eds) Proc 11th Conf Ital Assoc Oceanol Limnol AIOL, Genoa, p 353-362

Albertelli G, Covazzi-Harriague A, Danovaro R, Fabiano M, Fraschetti S, Pusceddu A (1999) Differential responses of bacteria, meiofauna and macrofauna in a shelf area (Ligurian Sea, NW Mediterranean): role of food availability. J Sea Res 42:11-26

Ankar S, Elmgren R (1976) The benthic macro- and meiofauna of the Asko-Landsort area (northern Baltic proper): a stratified random sampling survey. Contributions of the Asko Laboratory, University of Stockholm, 11, p 115

Arntz WE (1971) Biomasse und Produktion des Makrobenthos in den tieferen Teilen der Kieler Bucht im Jahr 1968. Kiel Meeresforsch 27:36-72

Bodin P, Boucher D, Guillou J, Guillou M (1985) The trophic system of the benthic communities in the bay of Douarnenez (Brittany). In: Gibb PE (ed) Proc 19th Eur Mar Biol Symp, Cambridge University Press, Cambridge, p 361-370

Bouvy M (1988) Contribution of the bacterial and microphytobenthic microflora in the energetic demand of the meiobenthos in an intertidal muddy sediment (Kerguelen Archipelago). PSZN I: Mar Ecol 9:109-122

Boyer M (1991) Annual variation of primary production, bacteria biomass and production in a Posidonia oceanica seabed in Gulf of Tigullio (Ligurian Sea). PhD thesis, University of Genoa

Ceccherelli VU, Mistri M (1991) Production of the meiobenthic harpacticoid copepod Canuella perplexa. Mar Ecol Prog Ser 68:225-234

Chardy P, Dauvin JC (1992) Carbon flows in a subtidal fine sand community from the western English Channel: a simulation analysis. Mar Ecol Prog Ser 81:147-161

Chardy P, Gros P, Mercier H, Monbet Y (1993) Benthic carbon budgets for the Bay of Saint Brieuc (western channel): application of inverse method. Oceanol Acta 16:687-694

Danovaro R (1993) Dynamics and trophic structure of meiofaunal assemblages in relation to the content and composition of particulate organic matter. PhD thesis, University of Pisa, p 256

Danovaro R (1996) Detritus-bacteria-meiofauna interactions in a seagrass bed (Posidonia oceanica) of the NW Mediterranean. Mar Biol 127:1-13

Danovaro R, Fabiano M (1996) Meiofaunal production in subtidal sediments of the Ligurian Sea: potential contribution of bacteria and microphytobenthos to the food demand. In: Albertelli G, De Maio A, Picazzo M (eds) Proc 11th Conf Ital Assoc Oceanol Limnol AIOL, Genoa, p 603-613

Danovaro R, Fabiano M, Boyer M (1994) Seasonal changes of benthic bacteria in a seagrass bed (Posidonia oceanica) of the Ligurian Sea in relation to origin and composition and fate of the sediment organic matter. Mar Biol 119:489-500

Danovaro R, Dell'Anno A, Martorano D, Parodi P, Marrale ND, Fabiano M (1999) Seasonal variation in the biochemical composition of deep-sea nematodes: bioenergetic and methodological consideration. Mar Ecol Prog Ser 179: 273-283

Danovaro R, Dell'Anno A, Fabiano M (2001) Bioavailability of organic matter in the sediments of the Porcupine Abyssal Plain (NE Atlantic). Mar Ecol Prog Ser 220:25-32

De Falco G, Ferrari S, Cancemi G, Baroli M (2000) Relation- ship between sediment distribution and Posidonia oceanica seagrass. Geo-Mar Lett 20:50-57

De Morais LT, Bodiou JY (1984) Predation on meiofauna by juvenile fish in a western Mediterranean flatfish nursery ground. Mar Biol 82:209-215

De Wilde PAWJ, Berghuis EM, Kok A (1986) Biomass and activity of benthic fauna on the Fladen Group (northern North Sea). Neth J Sea Res 20:313-323

Dye AH (1979) Aspects of the ecology of meiofauna in Mngazana Estuary, Transkei. S Afr J Zool 14:67-73

Dye AH (1983) Composition and seasonal fluctuations of meiofauna in a southern African mangrove estuary. Mar Biol 73:165-170

Edgar GJ (1990). The influence of plant structure on the species richness, biomass and secondary production of macrofaunal assemblages associated with western Australian seagrass beds. J Exp Mar Biol Ecol 137:215-240

Escaravage V, Garcia ME, Castel J (1989) The distribution of meiofauna and its contribution to detritic pathway in tidal flats (Arcachon Bay, France). In: Ros JD (ed) Topics in marine biology. Sci Mar 53:551-559

Fabiano M (1984) Production of the Ligurian coastal waters. II. Primary production. Nem Biol Mar Ocean 14:43-58

Faubel A, Hartwig E, Thiel H (1983) On the ecology of sublitoral sediments, Fladen Ground, North Sea. I. Meiofauna standing stock and estimation of production. Meteor Forsch-Ergebnisse 36:35-48

Feller RJ (1982) Empirical estimates of carbon production for a meiobenthic harpacticoid copepod. Can J Fish Aquat Sci 39:1435-1443

Feller RJ, Warwick RM (1988) Energetics. In: Higgins RP, Thiel $\mathrm{H}$ (eds) Introduction to the study of meiofauna. Smithsonian Institution Press, London, p 181-196

Fleeger JW, Palmer MA (1982) Secondary production of the estuarine meiobenthic copepod Microarthidion littorale. Mar Ecol Prog Ser 7:157-162

Gacia E, Granata TC, Duarte CM (1999) An approach to measurement of particle flux and sediment retention within seagrass. Aquat Bot 65:255-268

Gambi MC, Nowell ARM, Jumars PA (1990) Flume observations on flow dynamics in Zostera marina (eelgrass) beds. Mar Ecol Prog Ser 61:159-169

Gambi MC, Lorenti M, Russo G, Scipione MB, Zupo V (1992) Depth and seasonal distribution of some groups of the vagile fauna of the Posidonia oceanica leaf stratum: structural and trophic analyses. PSZN I: Mar Ecol 13:17-39

Gerlach SA (1971) On the importance of marine meiofauna for benthos communities. Oecologia 6:176-190

Guidetti P (2000). Leaf primary production in Posidonia oceanica: two reconstructing aging techniques give similar results. Aquat Bot 68:337-343

Heck KL, Orth RJ (1980) Seagrass habitats: the role of habitat complexity, competition and predation in structuring associated fish and mobile macro-invertebrate assemblages. Estuar Perspect 13:450-464

Heip C, Herman PM, Coomans A (1982) The productivity of marine Meiobenthos. Academiae Analecta (Klasse der Wetenschappen) 44:1-20

Heip C, Herman PM, Vincx M (1983) Variability and productivity of meiobenthos in the Southern Bight of the North Sea. Proc Verb Reun Int Explor Mer 183:51-56

Heip C, Vincx M, Vranken G (1985) The ecology of marine nematodes. Oceanogr Mar Biol Annu Rev 23:399-489

Herman PMJ, Vranken G, Heip C (1984) Problems in meiofauna energy-flows studies. In: Heip C (ed) Biology of meiofauna. International Meiofauna Conference, Gent (Belgium), 16-20 August 1983, 118:21-28 
Hicks GRF (1985) Meiofauna associated with rochy shore algae. In: Moore PG, Seed R (eds) The ecology of rocky coasts. Hodder \& Stoughton, London, p 36-56

Higgins RP, Thiel H (1988) Introduction to the study of meiofauna. Smithsonian Institution Press, Washington, DC

Kikuchi T, Pérès JM (1977) Consumer ecology of seagrass beds. In: McRoy PC, Helfferich C (eds) Seagrass ecosystems: a scientific perspective. Marcel Dekker, New York, p 147-193

Lasserre P, Renaud-Mornand J, Castel J (1976) Metabolic activities of meiofaunal communities in a semi-enclosed lagoon: possibilities of trophic competition between meiofauna and mugil fish. In: Persoone G, Jasper E (eds) Proc 10th Eur Mar Biol Symp. Universa Press, Wetteren 2: 393-414

Lawrence JM, Boudouresque CF, Maggiore F (1989) Proximate constituents, biomass and energy in Posidonia oceanica (Potamogetonaceae). PSZN I: Mar Ecol 10: $263-270$

Lepoint G, Nyssen F, Gobert S, Dauby P, Bouguegneau JM (2000) Relative impact of a seagrass bed and its adjacent epilithic algal community in consume diets. Mar Biol 136: $513-518$

Lindquist DG, Cahoon LB, Clavijo IE, Posey MH, Bolden SK, Pike LA, Burk LA, Cardullo PA (1994) Reef fish stomach contents and prey abundance on reef and substrata associated with adjacent artificial and natural reefs in Onslow Bay, North Carolina. Bull Mar Sci 55:308-318

Mateo MA, Romero J (1997) Detritus dynamics in the seagrass Posidonia oceanica: elements for an ecosystem carbon and nutrient budget. Mar Ecol Prog Ser 151:43-53

Mazzella L, Buia MC, Gambi MC, Lorenti M, Russo GF, Scipione MB, Zupo V (1992) Plant-animal trophic relationships in the Posidonia oceanica ecosystem of the Mediterranean Sea: a review. In: John DM, Hawkins SJ, Price JH (eds) Plant-animal interactions in marine benthos. Systematic Association, Spec Vol 46. Clarendon Press, Oxford, p 165-187

McIntyre AD (1964) Meiobenthos of sublitoral muds. J Mar Biol Assoc UK 44:665-674

McLachlan A, Kerley G, Rickard C (1996) Ecology and energetics of slacks in the Alexandria coastal dunefield. Landscape Urban Plan 34:267-276

Novak R (1982) Spatial and seasonal distribution of the meiofauna in the seagrass Posidonia oceanica. Neth J Sea Res $16: 380-388$

Novak R (1989) Ecology of nematodes in the Mediterranean seagrass Posidonia oceanica (L.) Delile. 1. General part and faunistics of the nematode community. PSZN I: Mar Ecol 10:335-363

Novak R (1992) Dynamic aspects of seagrass-nematode community structure. In: Colombo G, Ferrari I, Ceccherelli VU, Rossi R (eds) Marine eutrophication and population dynamics with a special section of the Adriatic Sea. Olsen \& Olsen, Fredensborg, p 277-284

Orth RJ, Van Montfrans J (1984) Epiphyte-seagrass relation-

Editorial responsibility: Kenneth Heck (Contributing Editor), Dauphin Island, Alabama, USA ships with an emphasis on the role of micrograzing: a review. Aquat Bot 18:43-69

Ott J (1980) Growth and production in Posidonia oceanica (L) Delile. PSZN I: Mar Ecol 1:47-64

Phillips RC, McRoy CP (1980) Handbook of seagrass biology: an ecosystem perspective. Garland STPM Press, New York, p 353

Pirc H, Wollenveber B (1988) Seasonal changes in nitrogen, free amino acids, and $\mathrm{C} / \mathrm{N}$ ratio in Mediterranean seagrasses. PSZN I: Mar Ecol 9:167-179

Probert PK (1986) Energy transfer trough the shelf benthos off the west coast of South Island, New Zealand. NZ J Mar Freshw Res 20:407-417

Renones O, Massuti E, Moranta J, Coll J, Moreno I (1995) Fish fauna of Posidonia oceanica seagrass meadows in Palma Bay (Balearic Islands). Cybium 19:201-206

Rudnick DT, Elmgren R, Frithsen JB (1985) Meiofaunal prominence and benthic seasonality in a coastal marine ecosystem. Oecologia 67:157-168

Schwinghamer P, Hargrave B, Peer B, Hewkins CM (1986) Partitioning of production and respiration among size groups of organisms in an intertidal benthic community. Mar Ecol Prog Ser 31:131-142

Soyer J (1985) Mediterranean Sea meiobenthos. In: Mo-raitouApostoloupolou M, Kiortsis V (eds) Mediterranean marine ecosystems. Plenum Publishing, New York, p 85-108

Velimirov B (1986) DOC dynamics in a Mediterranean seagrass system. Mar Ecol Prog Ser 28:21-41

Velimirov B (1991) Detritus and the concept of non-predatory loss. Arch Hydrobiol 121:1-20

Vranken G, Heip C (1986) The productivity of marine nematodes. Ophelia 26:429-442

Vranken G, Herman PMJ, Vincx M, Heip C (1986) A re-evaluation of marine nematode productivity. Hydrobiol 135: 193-196

Warwick RM (1980) Population dynamics and secondary production of benthos. In: Tenore KR, Coull BC (eds) Marine benthic dynamics. University of South Carolina Press, Columbia, p 1-24

Warwick RM, Gee JM (1984) Community structure of estuarine meiobenthos. Mar Ecol Prog Ser 18:97-111

Warwick RM, Joint IR, Radford PJ (1979) Secondary production of the benthos in an estuarine environment. In: Jefferies RL, Davey AJ (eds) Ecological processes in coastal environments. Blackwell Scientific Publications, Oxford, p 429-450

Watzin MC (1983) The effects of meiofauna on setting macrofauna: meiofauna may structure macrofaunal communities. Oecologia 59:163-166

Witte JIJ, Zijlstra JJ (1984) The meiofauna of a tidal flat in the western part of the Wadden Sea and its role in the benthic ecosystem. Mar Ecol Prog Ser 14:129-138

Zupo V, Nelson WG (1999) Factors influencing the association patterns of Hippolyte zostericola and Palaemonetes intermedius (Decapoda: Natantia) with seagrasses of the Indian River Lagoon, Florida. Mar Biol 134:181-190

Submitted: June 7, 2001; Accepted: November 26, 2001

Proofs received from author(s): April 24, 2002 